\title{
MEMBANGUN KEPEMIMPINAN OTENTIK DENGAN MODEL PENUGASAN
}

\author{
Arcadius Benawa \\ Character Building Development Center, BINUS University \\ Jln. Kemanggisan Ilir III No. 45, Kemanggisan-Palmerah, Jakarta Barat 11480 \\ aridarsana@yahoo.com
}

\begin{abstract}
Bina Nusantara (Binus) University as education organization has to improve itself to realize its motto "People, Innovation, Excellence". That's why Binus University have to implement the open system. By open system, BINUS University realizes practicability, flexibility, and openess. If it is done, BINUS University can guarantee to achieve its goal effectively and efficiently. Because of this, system approach is very important for the students as leaders in the next day who understand and make solution in overcome the complexity of problems in their organization. Everyone realizes that there is no problem like an island in itself. The problem is always linked with others. That's why, the problem should be understood as a system which has some subsystems. And every problem should be overcome by system approach, which accomodate wholistic approach and understand multifactors in it. In the learning process, assignment model used makes it effective or not in the system management, especially in education system in BINUS UNIVERSITY. By this reason, Eriksen's "Authentic Leadership: Practical Reflexivity, Self-Awareness, and Self-Authorship" (2009) very inspires the writer.
\end{abstract}

Keywords: authentic leadership, practical reflexivity, self-awareness, self-authorship, assignment model

\begin{abstract}
ABSTRAK
Universitas Bina Nusantara (Binus) sebagai organisasi pendidikan harus berbenah diri untuk mewujudkan motto " People, Innovation, Excellence ". Itu sebabnya Binus harus menerapkan sistem terbuka. Dengan sistem terbuka, BINUS menyadari kepraktisan, fleksibilitas, dan keterbukaan. Jika hal itu dilakukan, Universitas BINUS dapat dipastikan untuk mencapai tujuan secara efektif dan efisien. Karena itu, pendekatan sistem adalah sangat penting bagi siswa sebagai pemimpin pada masa mendatang yang memahami dan membuat solusi dalam mengatasi kompleksitas masalah dalam organisasi mereka. Semua orang menyadari bahwa tidak ada masalah yang besar. Masalahnya selalu berhubungan dengan orang lain. Itulah sebabnya, masalah harus dipahami sebagai suatu sistem yang memiliki beberapa sub-sistem. Dan setiap masalah harus diatasi dengan pendekatan sistem, yang mengakomodasi pendekatan holistik dan memahami multifaktor di dalamnya. Dalam proses pembelajaran, model tugas yang digunakan membuatnya efektif atau tidak dalam sistem manajemen, terutama dalam sistem pendidikan di Universitas BINUS. Dengan alasan ini, tulisan Eriksen (2009) "Authentic Leadership: Practical Reflexivity, Self-Awareness, and Self-Authorship" sangat mengilhami penulis.
\end{abstract}

Kata kunci: kepemimpinan otentik, refleksivitas praktis, kesadaran diri, kewenangan diri, model penugasan 


\section{PENDAHULUAN}

Fenomena kemenangan pasangan Jokowi-Ahok pada Pemilihan Gubernur (Pilgub) DKI, baik pada putaran pertama maupun kedua beberapa waktu lalu, seperti menjadi jawaban atas kerinduan masyarakat akan sosok pemimpin yang otentik, yang tahu diri bahwa jabatan adalah amanah atau panggilan untuk melayani kepentingan warga masyarakat. Pemimpin pelayan sebagaimana dipopulerkan oleh Robert K Greenleaf di New York pada tahun 70-an seperti mendapat angin segar bagi masyarakat Jakarta.

Universitas Bina Nusantara (BINUS UNIVERSITY), sebagai Universitas yang memakai nama "Nusantara" tidak berlebihan kalau berpartisipasi untuk menghasilkan sosok-sosok pemimpin otentik, yang mampu berefleksi, sadar diri, dan mampu melakukan self-autorship model Jokowi-Ahok. Pertanyaannya adalah melalui matakuliah atau kegiatan apa sosok-sosok pemimpin seperti itu dapat disumbangkan oleh sebuah Perguruan Tinggi, seperti BINUS UNIVERSITY ini?

Eriksen (2009) menginsipirasi penulis untuk mengulasnya sebagai pemikiran untuk diselenggarakan mata kuliah atau kegiatan yang dapat menghasilkan pemimpin otentik, beserta model pembelajarannya seperti yang disampaikan oleh Matthew Eriksen di BINUS UNIVERSITY dengan tinjauan dari manajemen sistem pendidikan. Apakah berdiri sendiri sebagai mata kuliah Character Building menambahkan yang sudah ada, seperti Self-Development, Spiritual Development, Interpersonal Development, dan Profesional Development? Ataukah diintegrasikan di dalam mata kuliah Character Building yang sudah ada?

Eriksen (2009) mengemas kuliah ini untuk para mahasiswa S2 setaraf MBA, namun tidak ada salahnya jika BINUS UNIVERSITY memodifikasi sedemikian rupa agar dapat diselenggarakan sudah sejak mahasiswa S1. Harapan penulis, ulasan ini dapat merangsang untuk munculnya pemikiran lebih lanjut yang lebih matang dan komprehensif demi BINUS UNIVERSITY dapat melahirkan pemimpinpemimpin otentik.

\section{Rangkuman}

Tulisan Eriksen ini ingin menegaskan bahwa untuk menjadi pemimpin yang otentik dan efektif, ia harus mampu mengembangkan kemampuan berefleksi dan memahami dirinya melalui pengembangan kesadaran dirinya (self-awareness). Dengan kemampuan leadership seperti itu ia bisa diharapkan dapat membuat keputusan yang tepat dan melaksanakannya dengan baik. Karena dengan kemampuannya itu memungkinkannya untuk dapat mengevaluasi sejauh mana efektivitas kepemimpinannya. Untuk itu, pertama-tama sebagai (calon) leader ia harus bisa mengidentifikasi dan menjelaskan tata-nilai dan kepercayaannya dan mempertimbangkan pengaruhnya pada kehidupan organisasi yang dipimpinnya.

Dengan mengeksplisitkan apa yang menjadi tata nilai dan kepercayaannya, diharapkan sebagai (calon) pemimpin ia dapat memiliki kesadaran diri (sense of self) yang jelas terhadap kepemimpinannya yang otentik. Kepercayaannya diungkapkan dalam bentuk kemampuan mengisahkan realitas dirinya (self-narratives). Kisah dirinya itu disharingkan dalam bentuk rekaman suara kepada teman-teman sekelasnya. Hal ini sungguh memfasilitasi proses belajar, memahami diri, dan berempati di antara para mahasiswa. Dan, tak mungkin mahasiswa sebagai calon pemimpin hanya dicekoki dengan pemahaman tentang kepemimpinan tanpa melibatkannya berproses dalam pemahaman dan penghayatan tentang kepemimpinan itu sendiri.

Jadi, tulisan ini memaparkan tentang model pembelajaran yang dikembangkan bagi para peserta kursus kepemimpinan berlevel Master of Business Administration (MBA) di Amerika. 
Program ini dilaksanakan pada semester pertama. Rata-rata program diikuti oleh 23 mahasiswa, baik yang belum berpengalaman kerja maupun yang sudah 28 tahun berpengalaman.

Perkuliahan itu ditempuh dengan model penugasan yang terdiri dari 3 bagian. Pertama, mahasiswa diminta untuk mengidentifikasi nilai-nilai personal mereka, mengartikulasikan makna dari nilai-nilai tersebut bagi mereka, merenungkan bagaimana mereka memperolehnya, dan dengan cara apa mereka menggelutinya untuk bisa melihat apakah tindakan mereka itu konsisten dengan tata nilai yang mereka anut. Lalu mendiskusikannya tentang konsekuensi-konsekuensi hidup mereka dari tata nilai yang mereka anut tersebut dalam konteks pengalaman kerja mereka maupun peran dan fungsi mereka sebagai (calon) pemimpin.

Kedua, mahasiswa diminta untuk menulis secara singkat tentang kepercayaannya dan mengartikulasikan bagaimana kepercayaannya itu menginformasikan tentang bagaimana mereka berusaha memimpin. Mahasiswa saling mendengar apa yang telah mereka rekam dari uraian yang telah mereka tulis kemudian mendiskusikannya.

Ketiga, berdasarkan tata nilai dan kepercayaan yang mereka identifikasi itu, para mahasiswa diajak untuk memperkembangkan prinsip-prinsip kepemimpinan yang mereka rencanakan untuk mereka ikuti saat menjadi pemimpin dan mengidentifikasi kriteria penilaian atas efektivitas dan otentisitas kepemimpinan mereka.

Jadi, penugasan bertajuk Kepemimpinan otentik: refleksi praktis, kesadaran diri, dan selfauthorship ini dimaksudkan sebagai latihan untuk memfasilitasi mahasiswa dalam memperkembangkan kemampuan berefleksi, kesadaran diri, dan self-authorship, sehingga para mahasiswa dapat memiliki dasar dalam mempraktikkan kepemimpinan yang otentik.

Refleksi praktis adalah bentuk pertanyaan yang eksistensial. Artinya, pertanyaan tentang diri seseorang yang dapat diberlakukan pada kesempatan lain sebagai bentuk tindakan retrospeksi diri. Refleksi praktis memungkinkan kita untuk memahami diri kita sendiri, cara kita berelasi dengan sesama, dan bagaimana kita berpartisipasi di dalam dunia sosial kita. Refleksi praktis juga memungkinkan seseorang untuk memilih mau jadi apa ia ke depannya, dan bagaimana ia mau bertutur kata maupun berperilaku. Melalui pertanyaan reflektif atas kepercayaan dan asumsinya, seseorang ditantang untuk dengan sadar memperhitungkan bagaimana kepercayaan dan asumsinya itu mempengaruhi seseorang dalam berelasi dengan sesamanya dari hari ke hari. Refleksi praktis menciptakan kesadaran diri sang mahasiswa tersebut.

Kesadaran diri adalah kemampuan menyadari pengetahuan tentang dirinya sendiri, tentang kepercayaannya, asumsinya, prinsip-prinsip yang dibangunnya, dan struktur perasaan serta konsekuensi-konsekuensinya dalam kehidupannya sehari-hari. Kesadaran diri merupakan prasyarat bagi terbangunnya self-authorship.

Self-authorship adalah kemampuan untuk merefleksikan kepercayaan seseorang, mengorganisasikan/menata pikiran dan perasaan seseorang dalam konteks (walau berbeda) pikiran dan perasaan orang lain, dan secara literer menjadikannya sebagai pikirannya sendiri. Meskipun selfauthorship itu memiliki dimensi kognitif, interpersonal, dan intrapersonal, fokus pembahasan ini adalah dimensi intrapersonal. Dimensi intrapersonal dari self-authorship ini muncul bila seseorang mengembangkan pemahaman dirinya lebih berdasarkan tata nilai dan kepercayaan yang dibangun secara internal daripada karena pengaruh eksternal.

Penugasan ini dibedakan dengan pendekatan serupa yang memfasilitasi pengembangan kepemimpinan yang di dalamnya memfasiltasi dan mengembangkan keterampilan refleksi praktis dan self-authorship melalui struktur dan pertanyaan-pertanyaan yang menghendaki jawaban dari para mahasiswa. Meskipun diketahui bahwa identifikasi tata nilai dan kepercayaan serta kreasi prinsip- 
prinsip kepemimpinan seseorang itu penting bagi pengembangan kepemimpinan seseorang, agar terusmenerus menjadi pemimpin yang efektif dan otentik ketika ia matang dan masuk ke dalam konteks kepemimpinan yang baru, ia harus dapat mempraktikkan refleksi praktis dan self-authorship.

Tata nilai, kepercayaan, dan prinsip-prinsip itu tidak bersifat bawaan di dalam diri kita, pun tidak merupakan bagian dari esensi kita. Semua itu dapat dan kerap kali berubah seiring dengan perkembangan tingkat kematangan kita. Semua itu tidak ada wujud materialnya, tetapi hanya dapat direalisasikan dalam ekspresi keberadaan kita di dunia nyata ini.

Jadi, melalui akuisisi keterampilan refleksi praktis dan self-authorship, mahasiswa dapat terusmenerus mengembangkan dasar pijakannya bagi tumbuh kembangnya pemimpin-pemimpin yang otentik di masa depan. Manfaat lain yang bisa dipetik dari penugasan ini adalah dampak positif dari pembelajaran melalui efek transformasional pada relasi para mahasiswa. Transformasi ini diperoleh melalui mendengarkan sharing mahasiswa di dalam kelas atas pernyataan-pernyataan kepercayaan yang telah mereka rekam sebelumnya. Sharing satu sama lain itu menciptakan ruang yang di dalamnya para mahasiswa dapat mulai melihat dan berinteraksi satu sama lain akan keunikan masing-masing individu yang ditentukan oleh sejarah pribadi mereka masing-masing, dan bukan oleh keanggotaan mereka di dalam kelompok sosial tertentu. Interaksi mereka pun menjadi lebih human seperti yang digambarkan lewat ungkapan Martin Buber dalam relasi ”Aku-Engkau” melalui promosi dialog reflektif di antara para mahasiswa.

Dialog reflektif memungkinkan para mahasiswa masuk ke dalam level yang lebih mendalam, sehingga pembelajaran mereka lebih bersifat empatik dan lebih memungkinkan mereka bisa belajar dari pengalaman satu sama lain. Dialog reflektif ini bentuk pembelajaran yang penting dan memberi sumbangan bagi terwujudnya kepemimpinan yang efektif dan memungkinkan kita untuk mengembangkan komunitas yang kritis di dalam kelas. Itulah yang memungkinkan terwujudnya pembelajaran yang menyertakan aspek emosi maupun kognisi. Lebih jauh memungkinkan pemimpin itu bisa memahami bahwa pengikutnya adalah manusia dan karenanya dalam memahami dan berinteraksi juga sebagai manusia. Dengan demikian kepemimpinannya pun menjadi lebih efektif. Akhirnya, para mahasiswa menyadari bahwa sharing kemanusiaan mereka itu dapat meningkatkan otentisitas mereka sebagai pemimpin berkat penerimaan dirinya.

\section{HASIL DAN PEMBAHASAN}

Ditinjau dari cara berpikir sistem, yang dipaparkan oleh Matthew Eriksen ini cukup menarik. Menurut Suriasumantri (1981: 7), cara berpikir sistem adalah pendekatan holistik terhadap suatu upaya menyelidiki sesuatu. Dalam hal ini, Matthew Eriksen mau menegaskan bahwa daripada sekadar mengajar mahasiswa dengan teori dan konsep tentang kepemimpinan yang otentik dan efektif lalu menguji kemampuan mereka dengan mengungkapkan kembali teori-teori tersebut kepada instrukturnya, lebih baik dengan sistem penugasan. Pasalnya, penugasan semacam ini memberi landasan bagi para mahasiswa dalam mengembangkan kepemimpinan otentik dan efektifnya di dalam praktik. Dengan melakukan self-authorship dan self-narrative, mahasiswa dapat mengembangkan dan mengartikulasikan tata nilai mereka, kepercayaan fundamental mereka, prinsip-prinsip kepemimpinan pribadi, dan kriteria dalam menilai efektivitas dan otentisitas kepemimpinan mereka dalam menyusun rencana pengembangan untuk meningkatkan efektivitas dan otentisitas kepemimpinan mereka.

Melalui sharing atas kepercayaan yang dinarasikan dalam pernyataan-pernyataan dan melalui dialog reflektif di dalam sharing tersebut, penugasan macam ini memfasilitasi bagi terjadinya transformasi relasi mahasiswa: bermula dari kategorisasi satu sama lain menjadi sharing kemanusiaan 
di antara mereka. Jenis relasi seperti ini menciptakan lingkungan yang memperdalam level pembelajaran yang diserap oleh para mahasiswa.

Selain itu, penugasan semacam ini juga lebih membuka peluang untuk mewujudkan pembelajaran yang tidak sekadar "objektif", tetapi juga menyertakan pengalaman dan perasaan subjektif mahasiswa. Greenleaf (1977: 18) mengatakan bahwa tidak ada yang berarti, kecuali bila terkait dengan pengalaman diri si pembelajar (Nothing is meaningful until it is related to the learner's own experience).

Akhirnya, mahasiswa menemukan latihan yang bermakna dan berdasarkan kebermaknaan ini memacu mereka untuk berupaya lebih besar untuk mendalaminya lebih lanjut. Penugasan ini memberikan struktur bagi para mahasiswa untuk mewujudnyatakannya yang kerap hanya menjadi konsep abstrak ke dalam konteks hidup mereka yang nyata sehari-hari.

Dari sudut pandang General System Theory pun, yang dipaparkan oleh Matthew Eriksen ini dapat diterima. Pasalnya, seperti yang dikatakan oleh Bertalanffy (2008: 30) bahwa General System Theory merupakan pendekatan lintas disiplin ilmu yang melihat suatu sistem sebagai seperangkat bagian-bagian yang independen, namun memiliki interaksi yang interdependen, dan bertujuan untuk menemukan prinsip umum dari suatu sistem untuk kemudian dapat diterapkan ke sistem lainnya. Sistem penugasan yang dipraktikkan oleh Matthew Eriksen pada para mahasiswanya itu jelas memasukkan disiplin ilmu lain di luar manajemen, seperti psikologi bahkan spiritualitas ke dalam kepemimpinan. Oleh praktik yang diyakininya membawa sukses di antara para mahasiswanya itu juga menghasilkan prinsip umum yang dapat diterapkan ke sistem lain. Artinya, apa yang dilakukan Matthew Eriksen tidak hanya bisa dipraktikkan untuk para mahasiswa formal di level MBA, tetapi juga bisa dipakai untuk team building bahkan juga bisa dimanfaatkan untuk trust building bila organisasi atau kelompok tertentu menghendakinya.

Ditinjau dari sisi organisasi sebagai sistem terbuka, paparan Matthew Eriksen ini juga memenuhi persyaratannya (Suriasumantri, 1981: 10). Artinya, ada input berupa para mahasiswa yang menjadi peserta kursus dengan spesifikasi jumlah 23 orang, dengan pengalaman kerja 0 - 28 tahun. Itulah energi yang masuk dari lingkungan eksternal. Lalu, ada through - put, yakni terjadinya transformasi energi di antara para mahasiswa itu sedemikian rupa, sehingga mereka saling memberi masukan melalui sharing pengalaman seputar tata nilai, kepercayaan, dan prinsip-prinsip kepemimpinan yang mereka anut. Adapun output-nya berupa energi yang dikembalikan ke lingkungan setelah input berproses bersama yang difasilitasi oleh instruktur yang memang berperanan penting. Sebab, padanyalah proses pembelajaran yang mengubah tacit knowledge menjadi eksplisit knowledge itu menjadi mungkin. Bagaimana sang instruktur sanggup memancing para mahasiswa untuk bisa dan mau mensharekan tata nilai, kepercayaan, dan prinsip-prinsip kepemimpinan yang dianutnya, sehingga mereka menemukan tipe kepemimpinan yang otentik. Hal itu tidak mungkin terjadi bila sang instruktur tidak mampu melakukan apa yang menjadi prasyarat dari terjadinya proses itu, yakni mampu berefleksi praktis, memiliki kesadaran diri, dan self-authorship (kemampuan diri untuk membangun pemahaman atas hal-hal yang terjadi di sekitarnya - pemahaman yang mengandaikan adanya kemampuan berpikir kritis). Cycle of events terjadi melalui tahapan-tahapan sejak dirumuskannya tujuan pembelajaran, yakni (1) meningkatkan kesadaran diri melalui perumusan, klarifikasi, dan artikulasi nilai-nilai utama, salah satu dari kepercayaan pokoknya, serta prinsip-prinsip kepemimpinan, juga dengan mendengarkan sharing untuk menemukan apa yang mirip dan apa yang berbeda; (2) mengidentifikasi kriteria penilaian mereka terhadap efektivitas kepemimpinan; (3) mengembangkan keterampilan berefleksi praktis; (4) mengembangkan keterampilan self-authorship; (5) mengalami kompleksitas dan keunikan peserta lain melalui sharing; (6) mensinergikan secara matang dan terbuka nilai-nilai, kepercayaan dan prinsip-prinsip kepemimpinan yang berbeda dengan miliknya sendiri; (7) menyadari problematik sifat natural dari stereotipe di antara peserta; (8) menghargai empati dan berusaha menjadi sosok yang empati; (9) mengembangkan komunitas yang kritis terhadap kepemimpinan (bdk. Bertalanffy, 2008:139). 
Untuk mencapai tujuan itu baik instruktur maupun peserta harus melakukan persiapan yang memadai. Instruktur tentu saja harus mematangkan konsepnya tentang nilai-nilai pribadi, selfauthorship, kesadaran diri, otentisitas, kepemimpinan yang otentik, self-narrative, dialog reflektif, dan refleksi praktis. Dengan demikian, ia bisa menyampaikan penugasan kepada peserta dengan baik. Maka ia juga harus menguasai tentang lembar tugas yang harus dikerjakan peserta, dan apa saja yang harus dilakukan peserta baik secara pribadi maupun kelompok, baik yang ditulis, direkam, maupun yang disampaikan secara lisan.

Sementara itu peserta harus menyediakan waktu dan diri sepenuhnya. Selain itu, peserta juga harus paham betul akan mekanisme yang akan terjadi di dalam kursus tersebut, baik menyangkut pemahaman, mental, dan aktivitas yang akan dilakukan baik secara pribadi maupun klasikal. Dengan prasyarat-prasyarat tersebut, kelas menjadi promotor dan inspirator bagi kelas berikutnya, sehingga terjadilah apa yang disebut cycle of events. Dengan demikian entropy terantisipasi dengan baik. Oleh karena sifat kursus yang demikian dinamis, sangat dimungkinkan terjadinya diferensiasi, karena selalu ada hal baru yang berkembang. Ada elaborasi-elaborasi dari temuan-temuan pribadi peserta maupun kelompok. Yang jelas juga terjadi equifinality, karena sistemnya memungkinkan peserta mencapai keadaan akhir yang berbeda dengan keadaan awal baik dari segi pemahaman, keterampilan, maupun kesadaran. Otentisitas kepemimpinan peserta sangat dipengaruhi dari kecapakannya berefleksi praktis, kesadaran diri, dan self-authorship-nya setelah dijumpakan dengan yang ada pada peserta lain sejauh ia tangkap dari sharing-sharing mereka. Di situlah peserta diperhadapkan pada feedback namun juga homeostasis, yakni kecenderungan untuk mempertahankan keseimbangan/stabilitas internal (Bertalanffy, 2008:161).

Dengan melihat cycle of events yang terbangun dalam paparan Eriksen sebetulnya juga terakomodasi yang diamanatkan oleh Senge (1990) dalam The Fifth Discipline, khususnya pada bagian III (Senge, 1990:139 dst.) bahwa melalui sistem penugasan dalam konsep pembelajaran yang dipaparkan Eriksen itu terbangun personal mastery pertama-tama pada diri instruktur, karena peran kunci bagi pelaksanaan model penugasan ini. Namun personal mastery juga terjadi di dalam diri para mahasiswa lewat proses pembelajaran yang melibatkan mereka secara aktif baik secara pribadi maupun klasikal, baik melalui penggalian pengalaman, pemahaman dan kesadaran diri maupun secara klasikal.

Selain itu juga terwujud adanya sistem pembelajaran dengan mental models, karena di dalamnya para mahasiswa mengungkapkan dan mengolah mental dirinya sebagai (calon) pemimpin yang otentik melalui sharing refleksi praktis, kesadaran diri, dan self-authorship-nya dalam proses pembelajaran tersebut. Dengan demikian juga terjadi apa yang disebut Senge sebagai share vision, yakni melalui sharing visi mereka tentang diri, nilai, kepercayaan dan prinsip-prinsip kepemimpinan yang mereka anut. Jadi, visi tentang kepemimpinan yang otentik itu diperoleh bukan dari sekadar transfer of knowledge dari pihak instruktur/dosen, melainkan karena dibangun dari visi yang bersamasama mereka sharekan.

Bahkan team learning pun terjadi karena pembelajaran sungguh terjadi bukan dalam komunikasi yang bersifat one way traffic melainkan di dalam tim. Instruktur sungguh hanya memfasilitasi, tetapi yang aktif menggali pengetahuan, pemahaman dan kesadaran adalah para mahasiswa itu sendiri secara pribadi kemudian disharekan di dalam kelas, kemudian diinternalisasikan untuk dapat merumuskan kepemimpinan otentik mereka masing-masing.

Dari sisi krisis makro di dunia pendidikan, sebagaimana diuraikan oleh Coombs (1970) pun, yang dikemukakan Eriksen bisa diterima. Artinya, Coombs melihat bahwa krisis pendidikan itu tidak hanya berkenaan dengan sistem, tetapi juga kepercayaan masyarakat terhadap pendidikan itu sendiri. Pemicunya tidak semata bersumber pada persoalan domestik, tetapi juga masalah-masalah internasional lainnya, seperti perubahan lingkungan, perubahan perkembangan berpikir dan kebijakan serta perubahan pemikiran dalam pendidikan (Coombs, 1970:145). Eriksen juga melihat bahwa sudah 
tidak zamannya lagi sistem pembelajaran itu hanya sekadar transfer of knowledge dari seorang instruktur/dosen yang ujiannya sebatas mahasiswa memuntahkan kembali pengetahuan yang pernah disuapkan instruktur/dosennya. Eriksen lewat paparannya ini mau menunjukkan bahwa mahasiswa juga memiliki pengetahuan, kesadaran, dan pemahaman sendiri yang bisa disharekan. Hal ini jelas sejalan dengan pandangan Piaget dan Vygotzky (Hergenhahn dan Olson, 2009: 313), para pencetus pembelajaran yang konstruktivis. Para mahasiswa dengan bantuan instruktur dapat berbagi pengalaman seputar pengetahuan, pemahaman, dan kesadaran mereka tentang nilai-nilai, kepercayaan, dan prinsip-prinsip kepemimpinan yang dianut. Dari situ mereka dapat mengonstruksi kembali pengetahuan, pemahaman, dan kesadaran mereka tentang kepemimpinan yang otentik.

Dengan demikian, dari sisi paparan Coombs tentang 5 faktor yang menjadi penyebab krisis makro di dunia pendidikan, Eriksen melalui tulisannya ini menurut penulis mengatasi penyebab keempat dan kelima, yaitu ketidakmemadaian output dan inertia atau tiadanya efisiensi (Coombs, 1970: 165), karena output-nya memuaskan dengan model penugasan ini dan dengan sistem penugasan dalam pembelajaran seperti yang dikemukakan Eriksen ini, proses dan hasilnya pun menjadi efisien. Artinya, pengetahuan, pemahaman, dan kesadaran yang ditemukan oleh para mahasiswa itu sungguh membangun citra otentik kepemimpinan mereka, sehingga mereka lebih siap membawakan diri sebagai pemimpin maupun dalam menghadapi staff ataupun anak buah yang mereka pimpin di dalam organisasi. Dengan demikian menjawab yang dipikirkan Coombs dalam menghadapi krisis makro di dunia pendidikan, yakni modernisasi manajemen pendidikan, modernisasi dosen/instruktur, dan modernisasi proses pembelajaran (Coombs, 1970:168).

Problem disparitas itulah yang pada periode berikutnya, Coombs menyorotinya terkait dengan adanya disparitas dalam dunia pendidikan, baik menyangkut disparitas ideal dan real, disparitas sosial ekonomi, dan lain-lain, sementara dunia pendidikan juga dihadapkan dengan semangat internasionalisasi yang sepertinya tak terbendung (Coombs, 1985: 211).

Oleh karena itu, untuk konteks BINUS University perlu adanya introspeksi: apakah siap dosen/instruktur mengikuti model pembelajaran dengan sistem penugasan seperti dipaparkan oleh Matthew Eriksen ini? Akan terasa berat bila dosen/instruktur BINUS UNIVERSITY masih diselimuti paradigma lama, yang masih bersifat one way traffic communication dalam sistem pembelajarannya. Bukankah aspek mastery personal di dalam diri dosen/instruktur itu harus kokoh, sebagaimana sudah jauh hari dicanangkan oleh Ki Hajar Dewantara bahwa seorang dosen/instruktur itu berperan sebagai role model: yang mau tak mau harus ing ngarsa sung tulada, ing madya mangun karsa, tut wuri handayani.

Terkait dengan hal itu bagaimana pula kesiapan peserta didik untuk aktif terlibat di dalam proses pembelajaran dengan model penugasan seperti dipaparkan oleh Eriksen? Namun bukankah sebetulnya peserta didik itu ikut saja pada instruksi sang instruktur/dosen. Inilah tantangannya: perlu modernisasi pada banyak bidang manajemen pendidikan, baik dosen/instruktur maupun proses pembelajarannya (Coombs, 1970:156). Dalam semuanya itu tidak luput dari konsekuensi logisnya yakni menyangkut penguatan dana pendidikan.

Dengan model penugasan ini pun model pembelajaran yang diamanatkan UNESCO pun terwujud, yakni memenuhi 4 pilar pembelajaran, seperti learning to know, learning to do, learning to be, dan learning to live together (Delors, 1998:85).

\section{SIMPULAN}

Lebih dari sekadar mengajar mahasiswa dengan teori dan konsep tentang kepemimpinan yang otentik dan efektif, lalu menguji kemampuan mereka dengan memuntahkan kembali teori-teori tersebut kepada dosen/instruktur, sistem penugasan semacam ini memberi landasan bagi para mahasiswa dalam mengembangkan kepemimpinan yang otentik dan efektif. 
Dengan melakukan self-authorship dan self-narrative, mahasiswa dapat mengembangkan dan mengartikulasikan tata nilai, kepercayaan, prinsip-prinsip kepemimpinan, dan kriteria dalam menilai efektivitas dan otentisitas kepemimpinan mereka. Selain itu mereka juga dapat membuat rencana pengembangan efektivitas dan otentisitas kepemimpinan mereka.

Melalui sharing kepercayaan yang mereka narasikan di dalam pernyataan-pernyataan dan melalui dialog reflektif di dalam sharing tersebut, penugasan macam ini memungkinkan terjadinya transformasi relasi mahasiswa: dari relasi berdasarkan pada kategorisasi satu sama lain menjadi sharing kemanusiaan di antara mereka. Relasi seperti ini menciptakan lingkungan yang kondusif bagi pembelajaran para mahasiswa.

Model penugasan semacam ini membuka peluang untuk mewujudkan pembelajaran yang tidak sekadar "objektif", tetapi juga subjektif karena menyertakan pengalaman dan perasaan mahasiswa. Robert Greenleaf mengatakan bahwa pembelajaran itu tidak akan berarti, kecuali bila pembelajaran itu terkait dengan pengalaman diri si pembelajar ("Nothing is meaningful until it is related to the learner's own experience," Greenleaf, 1977: 18).

Akhirnya, mahasiswa yang mendapatkan pembelajaran yang bermakna ini memacu mereka untuk berupaya lebih besar dalam mendalaminya lebih lanjut. Model penugasan ini memberikan struktur bagi para mahasiswa untuk mewujudkannya apa yang kerap hanya menjadi konsep abstrak ke dalam konteks hidup nyata sehari-hari.

\section{Saran}

Karena model penugasan semacam ini tidak hanya berhasil dilaksanakan di kalangan para mahasiswa MBA, tetapi juga di dalam seminar kepemimpinan, tidak ada salahnya kalau hal ini juga dilakukan di BINUS University sebagai latihan pembentukan tim di dalam berbagai kelompok atau organisasi mahasiswa BINUS University, supaya para anggotanya memiliki rasa menjadi bagian dari kelompoknya atau memiliki sense of belonging. Hanya memang harus dengan modifikasi tertentu agar sesuai dengan kebutuhan tim yang mau dibangun di BINUS University. Kalau perlu malah dikemas dalam suatu mata kuliah kepemimpinan, semacam leadership development, atau terintegrasi dalam profesional development. Untuk itu bisa disesuaikan alokasi waktunya untuk tiap bagian dari model penugasan ini, entah dengan diperkaya topik, atau kedalaman materi. Model penugasan ini juga bisa dimanfaatkan untuk membentuk kelompok yang diarahkan untuk pembentukan kepercayaan (trust building) jika memang ada krisis kepercayaan di dalam kelompok atau organisasi di BINUS University. Bagaimanapun, melalui sharing bisa terbangun kelegitimasian, kekuatan, tata nilai, dan kepercayaan di antara peserta.

Untuk itu, instruktur/dosen berperan sangat penting. Ia harus pandai mengajak peserta untuk terlibat di dalam sharing. Ia harus mampu memberi penekanan atas nilai tertentu dari sharing yang diungkapkan peserta. Ia juga harus bisa berterima kasih sebagai bentuk reinforcement terhadap peserta yang telah membagikan pengetahuan, pengalaman, tata nilai, maupun prinsip-prinsipnya. Konsekuensinya, BINUS University perlu mengadakan kaderisasi para instruktur/dosen untuk "mata kuliah" ini. Sehingga, prasyarat model pembelajaran seperti dipraktikkan oleh Eriksen dapat terealisasi di BINUS University, demi partisipasinya menghasilkan kader-kader pemimpin yang otentik, yang mampu berefleksi dan melakukan self-authorship, demi sumbangsih BINUS University bagi Nusantara. 


\section{DAFTAR PUSTAKA}

Bertalanffy, L. V. (2008). General System Theory. New York: George Braziller.

Coombs, P. H. (1970). The World Educational Crisis: A System Analysis. New York: Oxford University Press. (1985). The World Crisis in Education. New York: Oxford University Press.

Delors, J. (1998). Learning: The Treasure Within. Australia: UNESCO.

Eriksen, M. (2009). Authentic Leadership: Practical Reflexivity, Self-Awareness, and SelfAuthorship. Journal of Management Education, V 33, No. 6, p. 747-771. diakses di http:// www.jme.sagepublication.com.

Greenleaf, R. K. (1977). Servant Leadership. New York: Paulist Press.

Hergenhahn, B. R. dan Olson, M. H. (2009). Theories of Learning (Teori Belajar). Jakarta: Kencana.

Senge, P. M. (1990). The Fifth Discipline. New York: Currency and Doubleday.

Suriasumantri, J. S. (1981). System Thinking. Bandung: Binacipta. 